\title{
Computed Tomography Assessment of the Efficiency of Different Techniques for Removal of Root Canal Filling Material
}

\author{
Cristina DALL'AGNOL ${ }^{1}$ \\ Mateus Silveira Martins HARTMANN ${ }^{2}$ \\ Fernando Branco BARLETTA ${ }^{1}$ \\ ${ }^{1}$ Department of Dentistry and Endodontics, Dental School, Lutheran University of Brazil, Canoas, RS, Brazil \\ ${ }^{2}$ Postgraduate Program in Dentistry, Uningá Dental School, Passo Fundo, RS, Brazil
}

\begin{abstract}
This study evaluated the efficiency of different techniques for removal of filling material from root canals, using computed tomography (CT). Sixty mesial roots from extracted human mandibular molars were used. Root canals were filled and, after 6 months, the teeth were randomly assigned to 3 groups, according to the root-filling removal technique: Group A - hand instrumentation with K-type files; Group B - reciprocating instrumentation with engine-driven K-type files; and Group C rotary instrumentation with engine-driven ProTaper system. CT scans were used to assess the volume of filling material inside the root canals before and after the removal procedure. In both moments, the area of filling material was outlined by an experienced radiologist and the volume of filling material was automatically calculated by the CT software program. Based on the volume of initial and residual filling material of each specimen, the percentage of filling material removed from the root canals by the different techniques was calculated. Data were analyzed statistically by ANOVA and chi-square test for linear trend $(\alpha=0.05)$. No statistically significant difference $(p=0.36)$ was found among the groups regarding the percent means of removed filling material. The analysis of the association between the percentage of filling material removal (high or low) and the proposed techniques by chi-square test showed statistically significant difference $(p=0.015)$, as most cases in group B (reciprocating technique) presented less than 50\% of filling material removed (low percent removal). In conclusion, none of the techniques evaluated in this study was effective in providing complete removal of filling material from the root canals.
\end{abstract}

Key Words: gutta-percha, retreatment, computed tomography, root canals.

\section{INTRODUCTION}

Endodontic retreatment is indicated when signs or symptoms of infection are still present or reappear after the original treatment. The evolution of retreatment techniques and instruments associated to a better understanding of the factors involved in endodontic failure have pointed to conventional endodontic retreatment as the best choice.

Several methodological resources have been used in endodontic retreatment research, all of them showing some limitations. The currently used methods include longitudinal cleavage of the teeth (1), association of longitudinal and transversal cleavage for evaluation of the cervical, middle and apical thirds separately (2), cleavage associated to photographic records (3), and cleavage and photographs associated to the radiographic examination (4). However, longitudinal cleavage of teeth may result in displacement of the filling debris to be evaluated (5) and compromise the accuracy of the measurements. Other authors have used noninvasive methods. In the studies of Masiero and Barletta (6) and Gergi and Sabbagh (7), radiographs were taken after removing the filling material from the root canals, digitized and analyzed by means of software packages developed for civil engineering and architecture, the AutoCAD 2000 (Autodesk Inc., San Rafael, CA, USA) and AutoCAD 2004 (Mechanical Desktop Power Pack, 
Microsoft, Redmond, WA, USA), respectively. In recent studies $(8,9)$, the specimens were rendered transparent, photographed using a digital camera attached to a microscope and the amount of residual filling material was calculated using an image-analysis software (Comef 4.0; OEG Messtechnik, Frankfurt, Germany). These methods have limitations since radiographic and photographic images provide only two-dimensional information of a three-dimensional structure. Thus, the use of computed tomography (CT) has been proposed because it is a nondestructive and accurate method for calculating the volume of filling material (10).

The purpose of this in vitro study was to evaluate, using CT scans, the root filling removal efficiency of 3 techniques: hand instrumentation with K-type files, reciprocating instrumentation with NSK handpiece plus $\mathrm{K}$-type files coupled to an electric engine, and rotary instrumentation with NSK handpiece plus ProTaper system coupled an electric engine.

\section{MATERIAL AND METHODS}

Sixty extracted mandibular molars were radiographed and selected based on the following inclusion criteria: two canals in the mesial root, fully formed apices, no calcifications or internal resorption, no root fillings or prosthesis and mesial root with curvature between $20^{\circ}$ and $40^{\circ}$. The teeth were decoronated at the cementoenamel junction and the distal root was removed with a water-cooled double-faced diamond disc (KG Sorensen, Barueri, São Paulo, SP, Brazil) at low speed. The length of the mesial roots was standardized between 15 and $16 \mathrm{~mm}$. Root canal contents were removed using a size $10 \mathrm{~K}$-type file (Dentsply/Maillefer, Ballaigues, Switzerland) and 1\% sodium hypochlorite $(\mathrm{NaOCl})$ irrigation until the apical foramen was transposed. When the tip of the instrument penetrated and fit the apical foramen, the real canal length was recorded and the working length (WL) was calculated by subtracting $1 \mathrm{~mm}$ from this measurement.

All canals were prepared with a step-back technique up to a size $30 \mathrm{~K}$-type file (Dentsply/Maillefer) at the WL, stepping back with the subsequent four instruments (sizes 35, 40, 45, 50). The root canals were irrigated at each change of instrument with $2 \mathrm{~mL}$ of $1 \%$ $\mathrm{NaOCl}$ using an irrigating needle placed $3 \mathrm{~mm}$ from the WL. In order to standardize the procedure, the files were replaced after being used 5 times. The instru- mented root canals were filled with $17 \%$ trisodium EDTA for $3 \mathrm{~min}$, flushed again with $2 \mathrm{~mL}$ of $1 \% \mathrm{NaOCl}$ and dried with absorbent paper points.

The root canals were obturated with guttapercha cones and AH Plus sealer (Dentsply DeTrey, Konstanz, Germany) with lateral compaction of cold gutta-percha in the apical region followed by the use of a size $30 \mathrm{McSpadden}$ gutta-percha condenser (Dentsply/ Maillefer) placed $5 \mathrm{~mm}$ short of the WL in order to thermally soften and condense the gutta-percha. Buccolingual radiographs were taken (Insight; Eastman Kodak Company, Rochester, NY, USA) and the specimens were sealed with a temporary filling material (Cavit W; Espe Dental Medizin, Germany) and stored at $37^{\circ} \mathrm{C}$ in $100 \%$ humidity for 6 months.

After the aging period, the roots were numbered consecutively at random. Using a sheet of A4 paper, spaces corresponding to the roots were demarcated and identified with the number of each root (1 to 60). The roots were fixed on these locations with double-side tape and laid out side by side with their buccal surface turned to the left. Three-dimensional images of the roots were obtained using the GE LightSpeed Plus ${ }^{\circledR}$ multidetector CT scanner (General Electric Medical Systems, Milwaukee, WI, USA).

After obtaining CT scans from all specimens, the total volume of the root-filling mass in each canal was measured in $\mathrm{cm}^{3}$ using the $\mathrm{CT}$ scanner proprietary software (Volume Analysis 2 - Voxtool 3.0.54z software; General Electric Medical Systems), which automatically calculated the area of filling material previously outlined by an experienced radiologist (Fig. 1).

The teeth were then randomly assigned to 3 groups $(n=20)$. The temporary filling material was removed with a size 4 round bur (KG Sorensen, Barueri, SP, Brazil), thus forming a reservoir for the eucalyptol solvent (IodontoSul, Porto Alegre, RS, Brazil). One drop of eucalyptol solvent was applied at the canal entrance and left to act for $2 \mathrm{~min}$. A path was then created within the softened root-filling mass using sizes 25,20 and $15 \mathrm{~K}$-type files sequentially until WL was reached. After the root canal had been negotiated and the WL had been achieved, removal of gutta-percha continued with one of the three proposed techniques. Each time an instrument was removed from the root canal, it was cleaned with a sponge. At each instrument change, the root canals were irrigated with $2 \mathrm{~mL}$ of $1 \% \mathrm{NaOCl}$, the liquid was aspirated and another drop of solvent was 
applied. When the instrument reached the apical third, the use of solvent was discontinued. In order to standardize the procedure, each file was discarded after being used five times. Gutta-percha removal was considered completed when no filling debris was observed either on the instrument flutes or in the irrigating solution. The smoothness of canal walls was checked by tactile sensitivity using the last instrument.

Group A (control): filling material was removed with hand K-type files (Dentsply/Maillefer) according to a crown-down technique. Root canals were negotiated as described above and filling material removal started with a size $50 \mathrm{~K}$-type file and instruments of sequentially smaller sizes $(45,40$ and 35$)$ towards the apex until the WL was reached with a size $30 \mathrm{~K}$-type file. This instrument corresponded to the apical diameter established for the mechanically prepared specimens. Complete removal of gutta-percha was determined based on the above-mentioned criteria. All files were introduced to the point where resistance was felt from either the filling mass or from the internal anatomy of the canal. The instruments were inserted, rotated clockwise and counter-clockwise and removed.

Group B (Reciprocating technique): After root canal negotiation to the WL, reciprocating instrumentation was performed with K-type files (Dentsply/Maillefer) coupled to a handpiece (TEP SUPER - NSK; Nakanishi, Tochigi-ken, Japan) with 16:1 speed reduction and powered by an electric engine (TC motor 3000; Nouvag $\mathrm{Ag}$, Switzerland) at a constant speed of $935 \mathrm{rpm}$ and torque of $10 \mathrm{~N} / \mathrm{cm}$. Filling material was removed according to the crown-down technique starting with a size $50 \mathrm{~K}$-type file, followed by files of successively decreasing sizes (45, 40, 35 and 30$)$. Instrumentation was done with gentle push and pull movements towards the apex. Movement amplitude for initial penetration was no greater than $3 \mathrm{~mm}$ until the size $30 \mathrm{~K}$-type file reached the WL.

Group C (Rotary technique): The specimens in this group were instrumented using ProTaper Ni-Ti rotary instruments (Dentsply/Maillefer) coupled to a handpiece with a 16:1 speed reduction (TEP SUPER NSK, Nakanishi) powered by an electric engine (TC motor 3000). After root canal negotiation up to the WL, filling material was removed as per manufacturer's instructions: files S1 and SX, respectively, up to the middle third, followed by S1, S2, F1, F2 and F3 files, respectively, adjusted to the WL. The instruments were introduced into the root canal with gentle in-out movements parallel to the long axis of the canal, maintaining movement amplitude no greater than $3 \mathrm{~mm}$.

After root filling removal, the specimens were
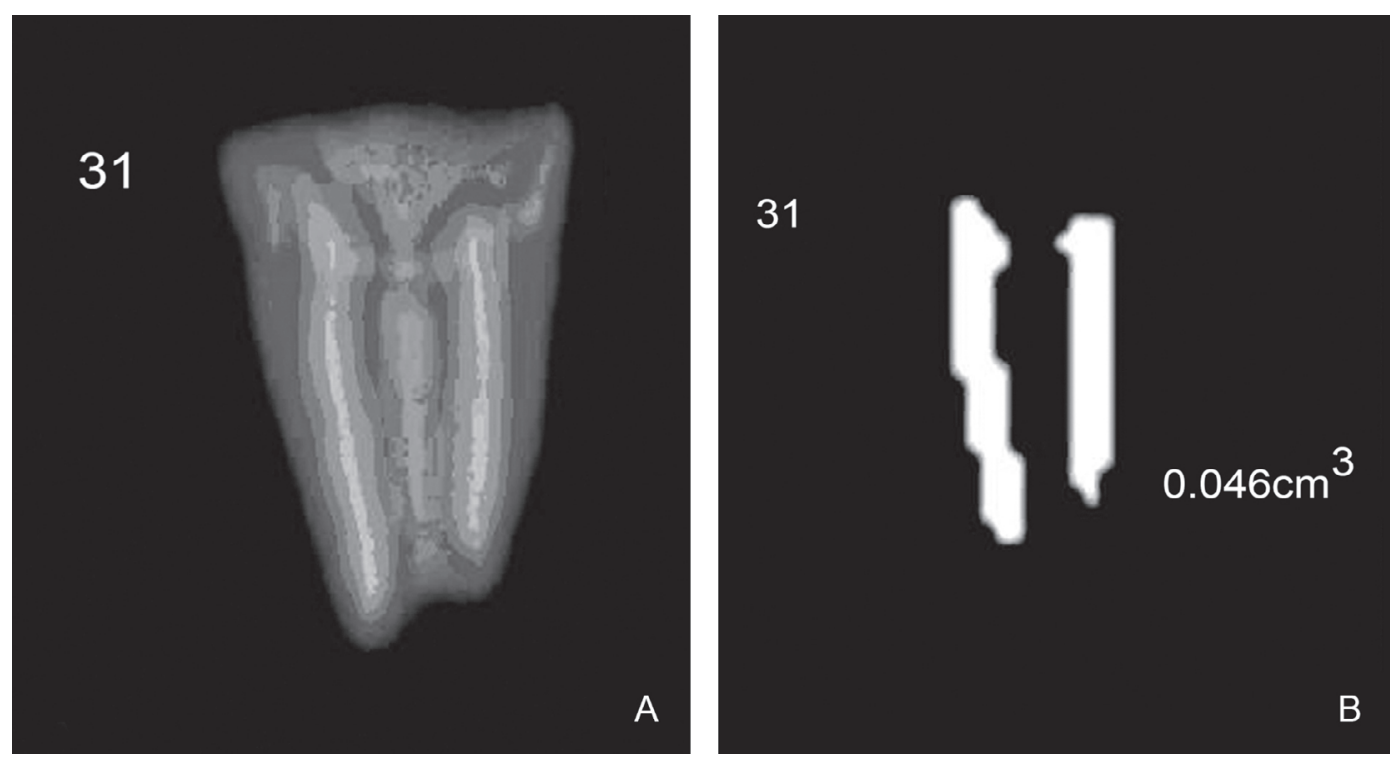

Figure 1. CT scan of the filling material in the root canals before filling material removal (A) and the selected filling material and its volume calculated in $\mathrm{cm}^{3}$ before the removal procedure $(\mathrm{B})$. 
placed back on the demarcated A4 paper sheet and fixed in the same positions as for the initial CT scanning. A new CT scanning of the roots was done. The volume of filling material remaining inside the canals was calculated in $\mathrm{cm}^{3}$ (Fig. 2) and recorded on a spreadsheet as final volume. The volume of residual filling material within the canals was analyzed using the same software and by the same experienced radiologist, who was blinded as to the group to which each image belonged.

Measurements of the volume of filling material before and after the removal procedures allowed assessing the percentage of filling material removed from the root canals by the different techniques. Data were analyzed statistically by one-way ANOVA and chisquare test for linear trend using SPSS software version 11 (Statistical Package for the Social Sciences Inc., Chicago, IL, USA). Significance level was set at 5\%.

\section{RESULTS}

None of the technique was able to completely remove the filling material from the root canals. The percent means and standard deviations of the amount of filling material removed in each group are shown on Table 1 . No statistically significant difference $(p=0.36)$ was found among the three groups regarding the per- cent means of removed filling material.

Analysis of the association between the percent filling material removal (high or low) and the techniques by chi-square test showed statistically significant dif-

Table 1. Amount of filling material $(\%$ mean \pm SD) removed from the root canals by hand and automated instrumentation techniques.

\begin{tabular}{cccc}
\hline $\begin{array}{c}\text { Hand } \\
(\mathrm{n}=20)\end{array}$ & $\begin{array}{c}\text { Rotary } \\
(\mathrm{n}=20)\end{array}$ & $\begin{array}{c}\text { Reciprocating } \\
(\mathrm{n}=20)\end{array}$ & $\begin{array}{c}\text { Total } \\
(\mathrm{n}=60)\end{array}$ \\
\hline
\end{tabular}

$65.74 \pm 11.96 \quad 63.01 \pm 18.66 \quad 57.89 \pm 20.73 \quad 62.21 \pm 17.53$

Table 2. Absolute and relative values of the number of specimens in each group considering the amount of removed filling material.

\begin{tabular}{ccccr}
\hline $\begin{array}{c}\text { Filling material } \\
\text { removed }\end{array}$ & Hand & Rotary & Reciprocating & Total \\
\cline { 2 - 5 } & $\mathrm{n}(\%)$ & $\mathrm{n}(\%)$ & $\mathrm{n}(\%)$ & $\mathrm{n}(\%)$ \\
\hline & $19(95.0)$ & $17(85.0)$ & $13(65.0)$ & $49(87.7)$ \\
$>50 \%$ & $1(5.0)$ & $3(15.0)$ & $7(35.0)$ & $11(18.3)$ \\
$<50 \%$ & $20(100.0)$ & $20(100.0)$ & $20(100.0)$ & $60(100.0)$ \\
Total & & & & \\
\hline
\end{tabular}
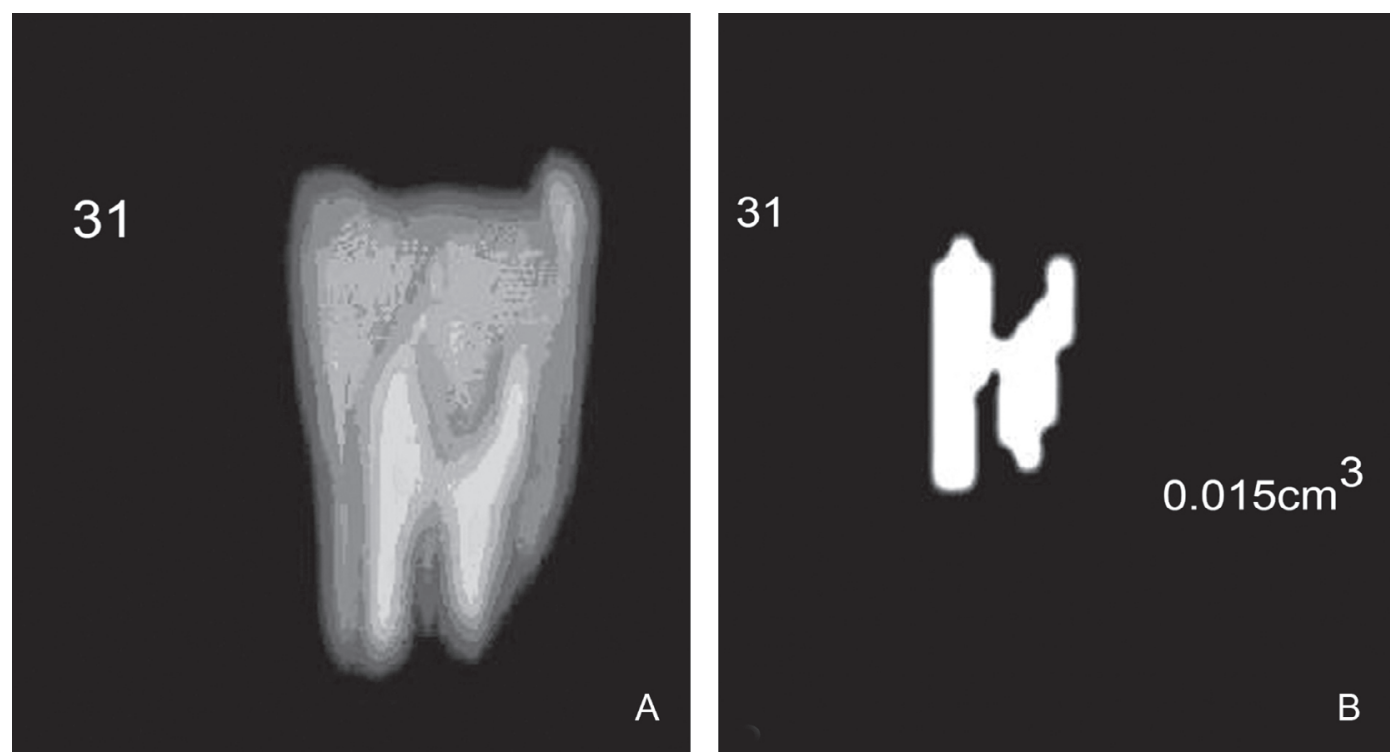

Figure 2. CT scan showing the filling material remaining inside the root canals after the removal procedure (A) and the selected filling material and its volume calculated in $\mathrm{cm}^{3}$ after the removal procedure (B). 
ference ( $p=0.015$ ), as most cases in group B (reciprocating technique) had less than $50 \%$ of filling material removed (low percent removal). Table 2 shows the absolute and relative values of the number of specimens in each group regarding filling material removal.

\section{DISCUSSION}

Mandibular molars were selected for this study because their root canals are usually flattened and present accentuated curvature, which are important anatomic variations that make their treatment difficult.

Rotary and reciprocating techniques were used for cleaning of root-filled canals in the present study because they are commonly used in endodontic retreatment research $(6,11)$. Moreover, automated techniques are time-saving and cause less fatigue to the dentist and less discomfort to the patient. Hand instrumentation technique was chosen as the control group because it is a well-known and widely used technique.

In this study, the teeth had their crowns removed at the cementoenamel junction even though this procedure does not fully reproduce the clinical conditions (5). Decoronation allows specimen standardization by eliminating some variables, such as dental crown anatomy and the root canal access, thus providing a more reliable comparison of the proposed retreatment techniques.

When the same instrumentation technique is used for the original treatment and root-filling removal, it is unlikely that previously undebrided areas are completely instrumented on the second occasion (12). As the crown-down technique was chosen for removing filling material from the root canals, the step-back technique was used for chemomechanical preparation.

Root canals were filled with AH Plus, which is a resin-based sealer of strong sealing ability due to great adhesion to dentin (13) and consequent reduced bacterial leakage, according to results reported by in vivo studies $(14,15)$.

The aim this study was to evaluate in vitro three endodontic retreatment techniques in canals previously filled by an experienced endodontist who followed an adequate treatment protocol and achieved a satisfactory amount of root canal enlargement, without unecessary removal of root structure. The methodology used in the present study, in which only root canal filling material was removed to verify the differences among the techniques, is supported by the study of Ferreira et al.
(5). If reinstrumentation were performed, although this variable could be controlled since the same operator performed all techniques, the canals could become very similar due to an increase in the diameter of the surgical canal and, thus, cleaner due to the performance of reinstrumentation, perhaps leading to some confusion in the results. In addition, the specimens used in the present study consisted in mesial roots of mandibular molars, which are usually thin and flattened. Therefore, if the diameter of the root canal is increased, it may lead to perforation in the risk area of the root.

The option for connecting the reciprocating system to an electric engine (6) was because compressed air-driven systems do not allow torque control and the air pressure variations may affect the rotational speed and torque (16).

During filling material removal, two Ni-Ti ProTaper S1 files fractured. These fractures most likely occurred due to 'torsional' failure, instead of 'flexural' failure, as the fatigue was controlled by the number of uses. The S1 instrument has a small and thin tip. If this tip should become engaged in a constricted lumen, the stress that builds up may quickly exceed the ultimate strength of such a small piece of material, thus leading the fracture (17).

One of the strong points of this study concerns the methodology for assessment of the filling material removed from the root canals. CT scanning was used in the present investigation in order to outweigh the limitations of the methodologies previously applied in endodontic retreatment studies, such as displacement of the filling debris during cleavage (1-5) and twodimensional imaging on a three-dimensional structure (6-9). Although this methodology has been extensively employed in endodontic instrumentation research $(18,19)$, its use in endodontic retreatment research is limited (10). This is a non-invasive method that allows visualization of morphological features in detail and does not require the destruction of the teeth (18). Moreover, CT scanning offers three-dimensional reproducible data and allows the assessment of endodontic retreatment by comparing the amount of debris inside the root canals before and after removal procedures.

Neither the hand nor the mechanical instrumentation techniques were capable of removing completely the root fillings, which is consistent with the findings of previous studies $(2,20)$.

The reciprocating group presented the worst 
results, which may be explained by the lesser friction of the stainless steel files against the root canal walls and by the decreased clinically perceived tactile sensitivity during filling material removal in comparison to the hand-instrumented group. Furthermore, the speed might have been insufficient, leading to gutta-percha plasticization instead of its removal.

Data on Table 1 brings the percent means of removed filling material in the 3 groups, which indicate that the amount of filling debris remaining inside the root canals was larger than expected. This fact might be explained by the use of AH Plus sealer, which has similar adhesion to root canal dentin walls to that of adhesive systems, producing resin tags that penetrate into the dentin tubules. Moreover, technical difficulties due to the anatomy of the root canals of the mandibular molars may have contributed for such results.

In a recent study of our research group (10), it was not possible to assess the removal of filling material segmented into thirds, since the CT image analysis software did not offer a tool to divide the structure analyzed into equal portions. Therefore, the volume of initial and residual filling material were analyzed as a whole. However, it was possible to observe visually that the greatest amount of residual filling material remained in the middle and, mainly, apical thirds, which was also verified in other studies $(6,11)$. This situation represents a poor prognosis for retreatment, since it may jeopardize the elimination of microorganisms that remain underneath the residual material at the region closest to the root apex.

According to the proposed methodology and based on the findings of this study, the following conclusions may be drawn: 1) None of the techniques was able to provide complete removal of the filling material from the root canals; 2) Comparing their percent means of filling material removal, the groups had similar results to each other; 3 ) There was significant difference in the percentage of specimens that presented low percent material removal $(<50 \%)$ and the reciprocating technique presented the largest number of specimens with low percent removal of filling material; 4) CT scanning can be used in retreatment research.

\section{RESUMO}

O objetivo do presente estudo foi avaliar a eficácia de diferentes técnicas na remoção de material obturador dos canais radiculares, através da tomografia computadorizada (TC). Sessenta raízes mesiais de molares inferiores humanos extraídos foram utilizadas. Os canais radiculares foram obturados e, após 6 meses, os dentes foram divididos aleatoriamente em 3 grupos, de acordo com a técnica de desobturação: Grupo A - instrumentação manual com limas tipo K; Grupo B - instrumentação oscilatória com limas tipo $\mathrm{K}$ acopladas a contra-ângulo NSK acionado por motor elétrico; e Grupo C - instrumentação rotatória com limas ProTaper associadas a contra-ângulo NSK acionado por motor elétrico. As imagens de TC foram feitas para avaliar o volume de material obturador encontrado no interior dos canais radiculares antes e após a desobturação. A região do material obturador foi demarcada nos dois momentos por um radiologista experiente e o volume foi calculado automaticamente pelo programa do TC. A partir do volume de material obturador inicial e remanescente de cada espécime o cálculo da porcentagem de material obturador removido. Os dados foram analisados pela análise de variância (ANOVA) e pelo teste qui-quadrado $(\alpha=0,05)$. A comparação das médias das porcentagens de material obturador removido não demonstrou diferença estatisticamente significante $(p=0,36)$ entre os grupos. Analisando a associação do percentual de material obturador removido (baixo ou alto) com as diferentes técnicas de desobturação, através do teste Qui-quadrado, encontrou-se diferença estatisticamente significante $(\mathrm{p}=0,015)$, com maior número de casos com menos de $50 \%$ de seu material obturador removido (baixa remoção) no Grupo B. Em conclusão, nenhuma das técnicas estudadas foi capaz de remover completamente o material obturador do interior dos canais radiculares.

\section{REFERENCES}

1. Moshonov J, Trope M, Friedman S. Retreatment efficacy 3 months after obturation using glass ionomer cement, zinc oxide-eugenol, and epoxy resin sealers. J Endod 1994; 20:9092.

2. Imura N, Kato AS, Hata GI, Uemura M, Toda T, Weine F. A comparison of the relative efficacies or four hand and rotary instrumentation techniques during endodontic retreatment. Int Endod J 2000;33:361-366.

3. Zuolo ML, Imura N, Ferreira MOF. Endodontic retreatment of thermafill or lateral condensation obturation in post space prepared teeth. J Endod 1994;20:9-12.

4. Barrieshi-Nusair KM. Gutta-percha retreatment: effectiveness of nickel-titanium rotary instruments versus stainless steel hand files. J Endod 2002;28:454-466

5. Ferreira JJ, Rhodes JS, Pitt Ford TR. The efficacy of guttapercha removal using Profiles. Int Endod J 2001;34:267-274.

6. Masiero AV, Barletta, FB. Effectiveness of different techniques for removing gutta-percha during retreatment. Int Endod J 2005;38:2-7.

7. Gergi R, Sabbagh C. Effectiveness of two nickel-titanium rotary instruments and a hand file for removing of guttapercha in severely curved root canals during retreatment: an ex vivo study. Int Endod J 2007;40:532-537.

8. Tasdemir T, Er K, Yildirim T, Celik D. Efficacy of three rotary NiTi instruments in removing gutta-percha from root canals. Int Endod J 2008;41:191-196.

9. Gu LS, Ling JQ, Wei X, Huang XY. Efficacy of ProTaper Universal Rotary retreatment system for gutta-percha removal from root canals. Int Endod J 2008;41:288-295. 
10. Barletta FB, Rahde Nde M, Limongi O, Moura AA, Zanesco C, Mazocatto G. In vitro comparative analysis of 2 mechanical techniques for removing gutta-percha during retreatment. J Can Dent Assoc 2007;73:65 (65a-65e).

11. Barletta FB, Lagranha SB. Análisis comparativo in vitro de diferentes técnicas de desobturación de conductos radiculares. Endodoncia 2002;20:189-196.

12. Wilcox LR, Swift ML. Endodontic retreatment in small and large curved canals. J Endod 1991;17:313-315.

13. Kopper PMP, Figueiredo JAP, Della Bona A, Vanni JR, Bier CA, Bopp S. Comparative in vivo analysis of the sealing ability of three endodontic sealers in post-prepared root canals. Int Endod J 2003;36:857-863.

14. Nunes VH, Silva RG, Alfredo E, Sousa-Neto MD, Silva-Sousa YT. Adhesion of Epiphany and AH Plus sealers to human root dentin treated with different solutions. Braz Dent $\mathrm{J}$ 2008; 19:46-50.

15. Pereira Cda C, de Oliveira EP, Gomes MS, Della-Bona A, Vanni JR, Kopper PM, et al. Comparative in vivo analysis of the sealing ability of three endodontic sealers in dog teeth after post-space preparation. Aust Endod J 2007;33:101106.
16. Yared GM, Bou Dagher FE, Machtou P. Failure of Profile instruments used with high and low torque motors. Int Endod J 2001;34:471-475.

17. Peng B, Shen Y, Cheung GSP, Xia TJ. Defects in ProTaper S1 instruments after clinical use: longitudinal examination. Int Endod J 2005;38:550-557.

18. Bergmans L, Van Cleynenbreugel J, Wevers M, Lambrechts P. A methodology for quantitative evaluation of root canal instrumentation using microcomputed tomography. Int Endod J 2001;34:390-398.

19. Peters OA, Peters CI, Schönenberger K, Barbakow F. ProTaper rotary root canal preparation: effects of canal anatomy on final shape analysed by micro CT. Int Endod J 2003;36:86-92.

20. Sae-Lim V, Rajamanickam I, Lim BK, Lee HL. Effectiveness of ProFile .04 taper rotary instruments in endodontic retreatment. J Endod 2000;26:100-104.

Accepted September 30, 2008 